\title{
Symbolic boundaries and school structure in New York and London schools
}

\section{Citation}

Warikoo, Natasha Kumar. 2010. Symbolic boundaries and school structure in New York and London schools. American Journal of Education 116, no. 3: 423-451.

\section{Published Version}

http://www.jstor.org/stable/10.1086/651415

\section{Permanent link}

http://nrs.harvard.edu/urn-3:HUL.InstRepos:23922469

\section{Terms of Use}

This article was downloaded from Harvard University's DASH repository, and is made available under the terms and conditions applicable to Open Access Policy Articles, as set forth at http:// nrs.harvard.edu/urn-3:HUL.InstRepos:dash.current.terms-of-use\#OAP

\section{Share Your Story}

The Harvard community has made this article openly available.

Please share how this access benefits you. Submit a story.

\section{Accessibility}




\title{
Symbolic Boundaries and School Structure in New York and London Schools
}

Appeared American Journal of Education, 2010.

\author{
Natasha Kumar Warikoo
}

HARVARD UNIVERSITY

Appeared in

\begin{abstract}
This article shows that an ethnically diverse student population leads to blurred ethnic and racial boundaries. Still, students in New York distinguish themselves much more along ethnic and racial lines than do London students. The evidence presented suggests that in addition to national-level differences, traditional British school structure, which provides continuity of peers through the Form Class as well as time for socializing, leads to less emphasis on ethnic and racial boundaries than in the anomic structure of traditional urban American public high schools. It follows that in order to promote ethnic and racial integration among teens, schools should not only serve integrated student bodies but also should maintain structures that present opportunities for students to bridge racial and ethnic boundaries. The study employs ethnographic data from schools in New York and London and 120 in-depth interviews.
\end{abstract}

Keywords: symbolic boundaries, race, ethnicity, school structure, comparative

\section{Author Biography}

Natasha Kumar Warikoo is Assistant Professor at Harvard University Graduate School of Education. Her forthcoming book, Balancing Acts: Youth Culture at School in the Global City (University of California Press, 2010) analyzes youth culture at diverse New York and London high schools. Her new research is on elite undergraduates' views on diversity and multiculturalism. 
Researchers have long established the benefits of racial integration in schooling for minority students throughout the life course (Crain \& Mahard, 1978; Dawkins \& Braddock Ii, 1994; Massey \& Fischer, 2006). Furthermore, the “contact hypothesis” suggests that a multiethnic student body will lead to less prejudice between groups, assuming equal status between the groups, common goals, and any prior prejudice not being extreme (Allport, 1954; Hewstone \& Brown, 1986). Less is known about the degree to which multiethnic school environments lead to weaker symbolic boundaries, or "boundary blurring" between ethnic and racial groups - that is, the degree to which multiethnic schools lead students to see their racial and ethnic groups as less distinct and separate, and the degree to which race and ethnicity determine social and status groups rather than, for example, taste preferences or extracurricular interests. Given the contact hypothesis's suggestion that integration decreases prejudice under the right circumstances, and the findings that integrated schools improve life chances for black students, we might expect that school integration blurs the symbolic boundaries between race and ethnic groups, as well. This article addresses this question of the symbolic boundaries of social relationships among teenagers attending multiethnic schools. It asks: to what extent does students of diverse backgrounds attending school together lead them to form social networks across ethnic and racial lines and to forgo racial and ethnic boundaries in peer groups, status, dating, and friendship? To what extent do race and ethnicity persist in defining the social lives of youth in these environments?

Aside from understanding the symbolic boundaries of teens in urban multiethnic environments, this research looks at schools cross-nationally by comparing a New York City school with a London school, in order to understand how school context affects symbolic boundaries among students. In addition to different histories of migration, racial formation, and segregation, the US and Britain traditionally have very different school structures. Urban public schools in the US usually house thousands of students and many are overcrowded, 
especially in neighborhoods of high immigration. ${ }^{i}$ US urban school structure is such that students do not spend a lot of social time in school, and they also don't see many peers for long periods: those who share a class may only do so only for one class, and in that class only for a year, or even just a semester. ${ }^{\text {ii }}$ In contrast, secondary schools in Britain, which usually serve ages 11-16, are structured around a Form Class. The Form Class first comes together in Year 7 (age 11), and has most subjects together for the whole school day, and for the next five years until age 16 when students finish secondary school. This article discusses how the contrasting school structures affect symbolic boundaries between students.

Previous research has found that school structure can influence ethnic and racial identities (Flores-González, 2002; Valenzuela, 1999). Conchas (2001), in research at three schools in the same building in California, found that one school structure perpetuated a forced choice between achievement/assimilation and failure/ethno-racial identification among Latino students, while another did not. In the research described below, I extend this research by comparing the traditional urban American high school context with that of British secondary schools, and by analyzing ethnic and racial boundaries rather than identities.

Lamont and Molnar (2002, 168) define symbolic boundaries as “conceptual distinctions made by social actors to categorize objects, people, practices, and even time and space,” (see also Barth, 1969; Lamont, 1992). Alba (2005) and Zolberg and Long (1999) have analyzed the boundary blurring of ethnic groups in the realms of citizenship, language, religion, and skin color (see also Wimmer, 2008a). Zolberg and Long (1999) define boundary blurring as "the tolerance of multiple memberships and an overlapping of collective identities hitherto thought to be separate and mutually exclusive,” (pp 8-9). They demonstrate how the state influences boundaries between ethnic groups, through policies related to citizenship, language education, and more (see also Wimmer, 2008b). In this article I integrate and extend Lamont's emphasis on investigating the distinctions that people 
make (for example, ethnic boundaries versus boundaries based on taste preferences) and Alba’s (2005), Zolberg and Long’s (1999), and Wimmer’s (2008b) discussions of state institutional influences on specifically ethnic and racial boundaries. I do so through a consideration of (1) the kinds of boundaries drawn by teens in multiethnic schools rather than a sole focus on ethnic boundaries, and (2) how not only national-level dynamics but also school structures influence those boundaries.

Some previous research has addressed the symbolic boundaries of teens in the US context in terms of their friendships and status hierarchies. Quantitative evidence shows that multiethnicity and fewer coethnics in school increase cross-race school friendships, with some ethnic and racial differences (Hallinan, 1982; Joyner \& Kao, 2000; Mouw \& Entwisle, 2006). Alan Peshkin (1991), in a study of the multiethnic high school in a working class town in California, found a great deal of interethnic "mingling” in terms of friendship and dating. In contrast, Perry (2002) found that American students attending a disadvantaged multiethnic high school in California stayed within their ethnic and racial groups for close friendships. Other research has found that athletics, success with the opposite sex, style, beauty, music tastes, and demonstrations of masculinity/femininity lead to peer status, suggesting that these are the criteria through which students draw symbolic boundaries (Adler \& Adler, 1998; Coleman, 1961; Eder, 1985; Milner, 2004). The research presented in this article extends the research described above by analyzing “superdiverse” (Vertovec 2007) high schools and doing so cross-nationally, allowing for an analysis of how urban American school structure impacts race relations in similarly diverse but structurally different schools.

In order to address the question of how multiethnicity—increasingly present in US and British cities (Fasenfest \& Booza, 2007; Fong \& Shibuya, 2005; Vertovec, 2007)— affects symbolic boundaries among students and how country-specific factors influence those 
boundaries, in this article I analyze the social groups and status hierarchies of teenagers in two multiethnic public high schools, one in New York City and one in London. I draw upon ethnographic data and 120 in-depth interviews. The article will demonstrate two findings. First, diverse peers lead to a significant degree of boundary blurring with respect to race and ethnicity in both cities. Second, although multiethnicity leads to blurred boundaries, in New York symbolic boundaries were defined much more by race and ethnicity compared to in London. The evidence suggests that, in addition to distinct degrees of racial segregation, national identities, and histories of migration, contrasting organizational structures of schools in the two cities influenced the continuing significance of race in symbolic boundaries among the New York student population, in spite of diversity in their school, and in contrast to the low salience of race and ethnicity for symbolic boundaries in the London school. Race and ethnicity mattered in London as well, but not nearly as much as they did in New York.

\section{METHODOLOGY}

This research was part of a larger project on youth culture among children of immigrants in New York and London (Warikoo, forthcoming). Both cities are diverse and are not dominated by one or two national-origin groups, in contrast to cities like Miami and Paris. Two schools, one in each city, were chosen for this research with three criteria in mind: (1) multiethnicity, with no majority group and significant numbers of second generation Indians and Afro-Caribbeans (two large ethnic groups common to both cities, for comparability); (2) class comparability across the two sites; and (3) traditional school structure for the city.

The New York school, York High Schooliii, lies on the border of Brooklyn and Queens. York High, like the borough of Queens in which it lies, is diverse. Hispanics (47\%) and Asians (about $34 \%{ }^{\mathrm{iv}}$ ) are the largest groups at the school, but the official statistics mask 
the internal diversity of the groups. Hispanics include significant numbers of Puerto Ricans and Dominicans as well as other Latino origin groups in smaller numbers. Asians include significant numbers of Indians, Indo-Caribbeans, and Pakistanis. Black students make up 13\% of the school population, and this includes African Americans and Afro-Caribbeans. Lastly, whites are $6 \%$ of the school population. Hence, there is no majority ethnic group at York High School. The school is home to over 3,000 students, 34\% of whom are eligible for free student meals, although the actual percentage of families living in poverty was likely to be much higher. ${ }^{v}$ Of the more than 700 students who entered the school in 2001, just 38\% graduated four years later (New York State School Report Card 2005-2006) (see Table 1). I focused my research on grades 9-11, ages 14-17.

\section{Table 1 about here}

In London, Long Meadow Community School sits in the borough of Brent. Over $60 \%$ of Brent's population is of non-British origin (2001 UK Census Key Statistics), and Brent ranks 81 ${ }^{\text {st }}$ out of 354 Local Authorities in England in terms of disadvantage (with 1 being the most disadvantaged in England (Office of National Statistics, Summary Statistics on Brent, 2004). The school's 1,100 students reflect the ethnic and racial diversity of the borough. No ethnic group predominates, and there is also a significant "mixed race" population. The largest ethno-racial groups are white British students (17\%), Indians (16\%), and Afro-Caribbeans (15\%); still, these groups together comprise less than half the student population. One-third of Long Meadow's students are eligible for free student meals. In terms of educational outcomes, in 2003 43\% of Long Meadow Year 11 (age 16) students attained 5 grades of C or above on the GCSE exams (The national average is 52\%) (2003 OFSTED Report) (see Table 1). vi Although Long Meadow hosts students from ages 11-18 (including a Sixth Form for ages 16-18), I focused my research on Years 10-11 and the Lower Sixth Form, which included ages 14-17, in order to coincide with the ages of my New 
York research. The measures above suggest that students in both schools are somewhat below average for their respective cities in terms of social class and academic achievement, although not the worst off in the two cities. The school structures are typical for their respective cities.

I spent six months in Long Meadow Community School, attending 3-4 days per week, and four months at York High, attending every day. I took on the role of observer rather than teacher's aide, to minimize the degree to which students censored themselves and their behaviors around me. In-depth interviews with second generation Afro-Caribbean and Indian students included questions on social status and school groups. In addition, in London I interviewed native white students, and in New York second generation Indo-Caribbeans ${ }^{\mathrm{vii}}$. There were twenty students of each ethnic group in each city (half girls and half boys), for a total of 120 in-depth, semi-structured interviews. I recruited students for interviews through the classes I surveyed for the project and then through other classes I observed, interviewing almost all the students who fit the interview criteria from particular classes in order to have as good a cross-section of the ethnic groups as possible. Because of York High School's greater diversity, I had some difficulty finding enough Indian and Afro-Caribbean students; hence, teachers helped me by introducing me to students they knew, as well. Interview respondents in both cities ranged in age from 14 to 18, with the exception of one 20-year old student in New York. In both cities, interviews lasted from 40 minutes to 90 minutes, and were subsequently transcribed. Transcripts were coded using ATLASti, and then analyzed by reviewing the quotes listed under different codes, and by using the matrix method of Miles and Huberman (1986) to examine gender, ethnic, and national differences in the interview data. Rather than being a prior hypothesis of the larger project, the findings presented in this article emerged from the data as I analyzed school social groups in students' interview responses by country. 
Because I found that the majority of black students at York High were African American with US-born parents, I approached a neighboring school in the same Board of Education Region, a school I call Harrison High School, to complete interviews with AfroCaribbeans. Although not ideal, because the schools were similar in terms of structure; race and class make-up of the student body; and academic achievement, I felt confident that this would not affect the research findings. Harrison High School lies less than 2 miles from York High School, and no other high schools lie between the two. Harrison High School's student body in 2003-2004 was quite similar to York High School’s in terms of ethnicity and race: 9\% non-Hispanic white, 26\% non-Hispanic black, 37\% Hispanic, and 33\% Asian and others (NYC Department of Education School Report Cards 2004). 49\% of Harrison’s over 3,500 students were eligible for free school meals. A school administrator at York High called Harrison their "sister school”. Many students at Harrison reported having friends at York, and vice versa. Fifteen of the 20 interviews with Afro-Caribbeans in New York were with students at Harrison.

\section{FINDINGS}

In what follows I analyze the symbolic boundaries of teens at both schools through two measures reported by students interviewed in both sites: (1) the nature of social groups; and (2) the peer status hierarchies. As expected by the contact hypothesis, many teens in both cities expressed and demonstrated fluidity with respect to ethnic and racial boundaries. However, I also found that New Yorkers had stronger racial and ethnic boundaries than their counterparts in London, in spite of many teens in both cities seeing themselves as fluid in their group boundaries or expressing a preference for weak boundaries between ethnic groups. I then discuss how differences in school structure could have led to the contrasting symbolic boundaries, in addition to national-level factors. 


\section{Social Groups at School}

In this section I present the variables of difference that youth in New York and London used to categorize each other, using interview responses to the questions "If you had to describe what the different social groups are at school, what would you say they are? Who hangs out with whom?" and "What groups in school do you feel most comfortable with? What groups in school do you feel least comfortable with?” Rather than assume a salient boundary marker such as race or ethnicity, I asked youth themselves about the social groups at their schools, to elicit what boundaries they themselves saw (Lamont, 1992; Wimmer, 2007).

$66 \%$ of students interviewed in New York described race and ethnicity groups when asked to describe the social groups at their school, in contrast to just $20 \%$ in London. New Yorkers often said things similar to Sanjay, when asked to describe the social groups at their school:

It depends. Some Punjabi people hang out with Punjabi, blacks with blacks, Spanish with Spanish. [Sanjay, Indian male, ${ }^{\text {viii }}$ New York]

Like many of his peers, Sanjay interpreted a question about social groups to be about ethnicity and race; these were the most salient group markers in New York. In addition to using race and ethnicity categories to describe their school's social groups, students in New York also described the social groups by level of popularity (16\%) and taste groups (16\%), such as punks and hip-hop listeners ${ }^{\mathrm{ix}}$. Similar to responses to questions on social groups, when asked an open-ended question about comfort among groups in school ("Which groups in school do you feel most/least comfortable with?”), over one-third of New York respondents named ethnic or racial groups as those they feel most comfortable with, and 20\% named ethnic or racial groups as those they feel uncomfortable with. 
Responses in London were more diffuse. Teens in London reported three main categories of social groups at school: (1) gender (24\%); (2) proximate groups—-their Form Classes (33\%) and what they did during lunchtime (20\%); and (3) consumption groups (24\%) - tastes in music and style. Form Classes spent their whole school days together from Year 7 to Year 10. Even during Year 10 students spent most of the day with peers from the Form Class (aside from science which was tracked, and two electives), and Year 11 students still had English class with their Form Classes, which most had known since Year 7. ${ }^{\mathrm{x}}$ Hence, most Form Classes grew to be quite close and fond of each other. One Year 11 Indian girl, Angela, explained how close her Form Class was:

My class is like,...really tight. I don't know, we just click. All of us just click with each other.... When we are in trouble, our class always...stick up for us.

This closeness formed after being together for five consecutive years. Later, Angela told me that she was going to be very sad at the end of the school year, because her Form Class would be breaking up and everyone would be going their separate ways-some to Sixth Form at other schools, some to work, and some to college.

When asked to describe the school's social groups, some used Form Classes as the unit of division, and others relayed within-Form social groups. For example, Frank, a white Year 10 student, said this when asked to describe his school's social groups:

I don't know really don't how to explain it, but you know Jason?... Yeah his table sits like at the back. And then you got my table sitting like right next to his.... And then we got all the like people who-geeks, sort of. [They] sit along near the window, near the front of the board...And then we've got the girls' tables there, and then, like Lucy, Habiba, and Lisa would sit in the middle.

Frank was describing the seating arrangement in his math class, which he had with his

Form Class. I asked Frank how he would characterize the groups:

My group is just the people who play football....Depends what classroom it is. Say if it's in maths. I will probably sit with the people who play football, like Derek and John and Vimal. But if I was in a different class, like sociology, I would sit next to Jason. 
Frank’s description shows that his social world at school is his Form Class-all of the students he mentions are from his Form Class. Frank bases his social group on his lunchtime activity (football), but when he sits in an elective class and all his classmates are not with him (sociology) he sits with the one student who is from his Form Class, Jason. I observed this seating arrangement in most elective and tracked classes in London—students usually sat with peers from their own Form Classes, regardless of taste preferences, ethnicity/race, or other kinds of social divisions.

In addition to identifying as Form Classes and groups within Form Classes, students in London broke off into social groups during school breaks, according to their activities during those times—20\% described lunch activities when defining the school's social groups. The entire school had two breaks during the school day, during which time all students were free to eat, play in the large school yard, sit in the library, or roam the school's hallways, since no classes were in session. London students had a variety of choices of physical space in which to spend their school breaks, while in New York, students were limited to the cafeteria. I always saw same-race groups of students in the New York cafeteria; this was not the case in London.

Finally, London students described taste groups at school (24\%). Abe, a 17-year old white Sixth Form student who had moved to London from the north of England a few years prior, described the school's social groups in terms of music:

I would say you could almost separate it with like music. You have got like people that like more Americanized music like hip-hop and stuff like that. Then you have got people that like garage, proper English garage. And then you have got people who like rock music and couple of people that like classical music.

After Form Class groups, taste groupings were the most common (along with gender) groups described by London youth in interviews.

\section{Table 2 about here}


Race and ethnicity were significant in London in two ways. First, as in New York, some students named race or ethnicity groups when asked to describe their school's social groups (20\%). Second, race was a part of the taste categories named by $24 \%$ of London youth, in that groups based on taste preferences were often racialized. For example, although many white and Indian students listened to hip-hop music, hip-hop and R\&B were seen as "black" music. On the other hand, rock and grunge music were seen as "white” music.

Grace, a Year 11 student who lives with her Nigerian mother and white English stepfather but spends a lot of time in the US with her Afro-Caribbean father, told me this:

It's like, there is all black in my group...There is one mixed race person and there is one white person, but the white person...she is more, like, you know, black. The way she behaves is like a black person, and she likes black things....And then you have the all white girls group. It's mixed-it's got, oh you might get a one black girl in it. She behaves like more like a white girl....But then you can get white people that act like black people, black people who act like white people....

In other words, London students defined racial categories in terms of taste and behaviors, rather than by the race of individuals in the group. These socially-defined groups are labeled "black”, and "white” because of the cultural heritage of the genre's contents rather than because of the members of that group, in contrast to New York, where groups were defined by the ethnicity of the individuals in them.

In terms of groups London students were comfortable or uncomfortable with, just one student named an ethnic or racial group. The most common response in London to which groups the respondent felt most comfortable with, besides "none”, was to name specific individuals in the student's Form Class (see Table 3).

\section{Table 3 about here}

Blurred Boundaries In addition to the specific responses described above, over one-third of respondents in both cities suggested loose social categories or that they themselves did not adhere to existing social groups. In interviews, after students named the different social 
groups I asked them to tell me which group they belonged to. $24 \%$ in New York and $13 \%$ in

London excluded themselves from the social group typology they described to me. For

example, Jennifer, a 20-year old senior in New York whose parents are Puerto Rican and

Afro-Trinidadian, told me this:

From what I have noticed, a lot of Puerto Ricans hang out with each other. A lot of Italians hang out with each other. And a lot of African Americans hang out with each other. And it's like, it's crazy because everybody should just hang out with everybody, that's the way how I feel. Everybody should just branch out.....

I asked Jennifer which group she would be in:

Well I would be in all of them. It really doesn't matter to me....

Jennifer's sentiments suggest a sense that extending beyond one's ethnic group is the morally correct thing to do.

Boys echoed these sentiments. Sanjay, quoted earlier, described a similar situation

when I asked him about his New York school’s social groups:

Some Punjabi people hang out with Punjabi, blacks with blacks, Spanish with Spanish. I like hanging out with mixed, not like all Punjabis, but all others, everybody mixed.

Dan, an Afro-Guyanese student who came to the US at age 6, explained to me that the difference between his cosmopolitan tastes and his friends' boundary maintenance sometimes led to conflicts:

$N$ : So which groups at school do you feel most comfortable with?

$R$ : There's not really one group that I feel comfortable with at school. Sometimes I might hang out with the goths or I might hang out with the thugs or what not. Every time they ask me a question, I try and blow it off because it might be racist: 'Oh, why you hang out with these people? Man, they are crazy! Those white boys are nuts!' ...And my white friends are like, you know, 'Why you hang out with those thugs?' I am like, 'What are you talking about? They are my friends, just like how you are my friends! It doesn't really matter.'

Like Jennifer above, Dan seems to draw a moral boundary around being open to myriad cultural influences and a diverse set of friends. 
As in New York, 13\% of Londoners were quick to point out that they themselves did not stick to one group. For example, Terry, a Year 10 Afro-Caribbean, told me of his wanderings between groups during lunchtime when I asked about school social groups:

There is groups, but me personally I don't just hang around with one person. Me, I like to move like, so I keep in touch with all my friends. So I might be with one group that'll be speaking, then I go to another group speaking, might play football with some of my friends....I don't like stick with one particular people.

I asked Terry how the groups are different:

Some might be just sitting down, talking. Some might be playing football. Some might be doing different stuff like in music room....

Terry, like many of his London peers, defines the social groups by break time activities. Yet, he sees himself as transcending group boundaries. These youth valued omnivorous social networks, and preferred to see themselves as transcending group boundaries—both in London and in New York—rather than as confined to one group. They perceived peers to have more rigid symbolic boundaries than themselves. They felt a sense of self-worth in their willingness to engage with diverse peers, and expressed frustration with others’ lack of understanding of other groups. This finding is similar to research suggesting that elites in the US value “cultural omnivorousness” over single, elite taste preferences (Bryson, 1996; Erickson, 1996; Peterson \& Kern, 1996; Peterson \& Simkus, 1992). These findings suggest a value in social omnivorousness, and which is not confined to elites.

In addition to the $24 \%$ in New York and $13 \%$ in London describing groups but excluding themselves from the typology, another 13\% in New York and 22\% in London said that in fact there weren’t fir group boundaries at their schools. For example, Christine, an Indo-Caribbean girl in New York, told me this when I asked her what the social groups in her school were:

I don't think they have groups like that. Because to me everyone-they hang out with whoever they want to hang out with....It's not like, if you think 
somebody is popular then you want to become friends with them. It's like,...they don't have that here.

Like some students in New York, many in London were quick to point out that the social groups were fluid. Beatrice, a white Sixth Form student (age 16), explained:

I think one of things I quite like about this school is that it's not like...really obvious defined groups of people who, you know, are labeled in certain ways and they only hang out with certain people and things like that. It's not like that at all.... think everyone is kind of mixed and I think that comes a lot from the different ethnic groups as well....It's nice, I kind of like it.

Beatrice points out that the social boundaries between groups are quite loose, and not based on ethnicity.

Lastly, although New Yorkers were more likely to express racial barriers in describing which social groups at school with which they felt most or least comfortable, the most common response overall in both cities to the questions "What groups in school do you feel most comfortable with?" and "What groups in school do you feel least comfortable with?” was “none” (see Table 3). Hence in both New York and London I found some degree of blurring of symbolic boundaries with respect to school social groups; still, New Yorkers defined their symbolic boundaries in school much more along racial and ethnic lines than did their London counterparts. Next I turn to the status hierarchy in both cities, to further understand the nature of social divisions in the two contexts.

\section{Social Status}

Eder and Kinney (1995) define two types of status among youth: popularity and peer status. They operationalize peer status by the question, "If you could choose any students in your grade to hang around with at school who would they be?” (page 303); and popularity by those who students define as popular. However, youth equate the two. Merten (1997) found that girls define popularity as having the recognition of classmates and being "sought after as a friend” by peers. In Milner’s (2004) study of the status systems of high school students, he 
asked college students to recount the status systems of their high schools; when they did so, many operationalized status as popularity, indicating that popularity is synonymous with status in more lay terminology among youth.

Because I was concerned with students' perceptions of status among peers, I asked interview respondents about popularity. I asked students to describe the most popular and least popular groups at school; why those groups were popular/unpopular; and where they saw their own location in that hierarchy. Note that this question asks about groups rather than individuals, because of my interest in symbolic boundaries.

Social Hierarchy in New York Milner (2004) suggests that large, racially diverse high schools in the US have more pluralistic and less hierarchical social organization. Moreover, his research suggests that black and white students in a mixed high school will develop parallel status hierarchies. In the large, multiethnic high school of my research in New York, I found neither to be the case. At York High School, a status hierarchy that encompasses all ethnic and racial groups existed. Perhaps the large number of different ethnic and racial groups prevented sub-hierarchies from forming.

When I asked New York students to tell me about the popular groups in their school, $43 \%$ mentioned one or more race or ethnic groups. Most commonly, the race group was black students (followed by Hispanics), sometimes related to the perception that black students engaged in delinquent behaviors. For example, when I asked Maurice, an IndoTrinidadian student who came to New York at age 10, who was most popular in his school, he told me this:

Black students are the most popular, because they think they're hard, they like to fight. They make people scared of them... by the way they dress. It's different, extremely big clothes-pants down to their knees,...People are scared of them, so they want to hang out with them so they don't get beat up.

Note that Maurice begins his response with a racial identity. He then points out that his peers look to those who are feared for protection from bullying, giving them higher status. Many 
students, like Maurice, put a negative spin on their description of the popular students at school. Although peers may recognize popular students' status, they don't always approve of those peers, or even like them. This perhaps is due to popularity and status being defined not by who peers like, but sometimes by who they fear. Popular but feared youth have the power to enforce conformity to cultural norms through, for example, not befriending those perceived as wearing uncool clothes or not comporting themselves in a "cool” way. 37\% of respondents in New York described some form of misbehavior or bullying when asked about who was popular in their school. ${ }^{x i}$ This finding resonates with Lamont's (2000) research on working class men, in which she documents how working class men define their moral boundaries in opposition to those of upper class, high status men, whose values they express distaste for.

Race/ethnicity also commonly defined unpopular groups in New York. When I asked students in New York to describe the unpopular students in their school, 46\% mentioned race or ethnicity groups, and of those the majority mentioned Indians or Punjabis - this was over half of the students who gave a specific answer to the question (besides "I don't know” or "no one is unpopular"). ${ }^{\mathrm{xii}}$ The other group mentioned more than once as unpopular (but half as much as Indians) was whites.

In addition to race and ethnicity, 23\% of New York students described the unpopular students as those who didn’t speak much, didn’t have friends, or didn’t socialize outside of school hours. As with popularity, this behavior was racialized by some, usually as Indian. For example, Gwen, an Afro-Caribbean girl in New York, told me that Indians are unpopular at her school, because they leave right after school and don’t participate in afterschool activities:

The Indian group...are not that popular. Because they kind of like keep to themselves....Like after school's done they are out of here. They are not involved in anything. 
Similar to peers' responses, Gwen first indicates the ethnicity associated with the unpopular group.

Descriptions of popularity and unpopularity in New York illustrate the interplay of race and individual behaviors in determining peer social status. For example, peers might assume an Indian student does not socialize outside of class and hence label her unpopular, unless she demonstrates otherwise. This is the converse of the mechanism for popularity, whereby black students were stereotyped as having the toughness and correct interactional style to earn high peer status, unless they demonstrated otherwise. Students in London, as we will see, had a similar interaction between race and individual behaviors. However, as with the drawing of group boundaries, race and ethnicity mattered less in London.

Social Hierarchy in London Students in London most commonly attributed popularity, or status, to: (1) students who were "known", "loud" or socialized in a big group in school (31\%); (2) those who made popular taste and consumption choices (20\%); (3) individuals in their Form Classes (16\%); and (4) misbehavior or bullying (15\%).

\section{Table 4 about here}

Race was related to tastes in London, in that hip-hop style had high status, and hip-hop was racialized as black. However, taste was more salient than race and ethnicity, as it was for social groups in London. For example, Terry, an Afro-Caribbean Year 10 student, told me this about the popular students in his school:

That they are getting with the trend. They know about things. They know about the latest music. They know about the latest clothes. Well, they know about the latest trainers [sneakers]. They know about slang. Just the way they---it's mainly about what they wear, and the way they act. Just like people might know more slang. People might dress more slick...

Terry identified the popular tastes, language, and behavior, as leading to popularity. I then asked Terry if the popular students tend to be a particular race. He was in two minds:

I'm not sure....Tend to be, because there is some that are white and-no, I think-I am not sure. I think black, I think black, because most people in this 
school, most people I know that seem to be popular, they are black. Jason [mixed race student] is, yeah popular. But Chris is popular, and he is white. So there is some people that are white and popular too.

In other words, the popular students tend to be black, but race does not determine one’s level

of popularity. Rather, the mechanism by which most (but, crucially, not all) popular students are black is a perceived greater propensity of black students to consume hip-hop style, due to hip-hop’s racialization as black.

In terms of low status, students in London most frequently described unpopular students as loners - $36 \%$ of students said that the unpopular students at school were the quiet ones and/or the students who are alone most of the time. Aside from these responses, "grungies" (students preferring grunge, rock, and/or punk music and style) were cited by 9\%. London students here, also, placed less emphasis on race than did their New York counterparts: only 2 students in London (4\%) mentioned an ethnic or race group when asked to describe the unpopular groups at school, in contrast to $46 \%$ in New York (see Table 5).

\section{Table 5 about here}

In this section I have outlined the status hierarchies in New York and London, as defined by students’ perceptions of popularity and unpopularity. As with social groups, I found that ethnicity and race were more salient in New York. Given the differences between London and New York symbolic boundaries, what explains them? The evidence strongly suggests, as I will show, that school structure plays an important role in the contrasting symbolic boundaries between students in the two cities.

\section{THE IMPACT OF SCHOOL STRUCTURE ON SYMBOLIC BOUNDARIES}

Recall that London students often used the Form Class as their social unit of analysis: $33 \%$ named Form Class groups or subgroups as the school's social groups, and another 20\% of Londoners described school social groups by lunchtime activities. Also, 16\% named Form Class individuals as who was popular in their school. These findings suggest that the school 
structure in London—especially students following a Form Class for almost the whole school day for five years, and two daily school-wide lunch breaks—-has an influence on symbolic boundaries. Below I describe the contrasting school structures in London and New York in more detail.

York High and Long Meadow had quite different school structures, and both were typical for their respective cities. New York City’s public high schools operate on a semester system, so that classes change not only every September, but also every February. There are no set "homeroom” or "registration” classes that travel from subject to subject together; rather, students encounter different configurations of peers in every subject. In addition, as with most public high schools in Queens, York High is vastly overcrowded, schooling over 3,000 students. As a result, the school is forced to educate students in shifts, so that although individual students only attend school for 7-8 periods a day, the school runs for 12 periods a day. Some students start school before 7:30 AM, and others finish after 4 PM. Related to the overcrowding problem is the lack of morning or afternoon homeroom period—students need to arrive and leave the building as quickly as possible.

Lunchtime poses a great challenge for overcrowded schools. York High School solved this problem through a staggered, optional lunch period. That is, the cafeteria served lunch starting at $4^{\text {th }}$ period (starting at 9:45 AM) and continued through $8^{\text {th }}$ period (ending at 1:35 PM). When scheduling their classes, students could state a preference to have a lunch period or not (and have 7 consecutive classes instead), but this preference was not guaranteed, and the schedule would change (along with the peers encountered during that lunch period) twice a year, with the start of each new semester in September and in February. Some students preferred to have lunch yet did not get one. More commonly, students told me they preferred to go straight through the day with no lunch break-perhaps partly because the food was not tasty, but more commonly it seemed the preference stemmed from a desire to 
avoid the social anxiety of not knowing anyone during the scheduled lunch period. One teacher told me that she allowed a few students she knew well (due to their being in a special English class that stayed together and with the same teacher for two years) to come to her classroom and sit in the back quietly during their lunch breaks. I observed 3-4 students regularly taking up her offer. When trying to schedule an interview with one Indian student he told me that I wouldn't find him in the cafeteria during his lunch period because he went home every day for lunch (against school rules). Many New York students spent their lunch period in the library when they could get in (in addition to often being closed, the library had space limitations). The library was a safe space for students who didn’t share their lunch period with any friends, because they could sit quietly and read a magazine, or chat with someone who might have sat at their table. Students were not permitted to wander the halls during their lunch period, since classes were in session during all lunch times. There was also no outdoor space for them to play in, since the schoolyard was taken up by trailers that served as makeshift classrooms, another solution to the problem of overcrowding.

Who one eats with is an important marker of social groups (Milner, 2004). Lunchtime illustrates well the dilemma faced by students in large urban high schools: how to deal with anonymity and the lack of opportunities to form strong, trusting friendships, especially with peers who on the surface seem quite different from oneself. The structure of traditional urban public high schools in the US like York High School leads to this dilemma. The large size (recall that York has over 3,000 students); class structure that mixes students up every period for 7 periods, and again every September and February; no homeroom time; and limited lunch breaks, if any, create a situation in which students have little opportunitydown time at school, or extended interaction with particular peers- to develop close relationships with peers who they don't immediately identify with. Some recent immigrants from India I met at York High explained to me that when they arrived in the school other 
Punjabi students noticed them and approached them in the hallway, asking many questions and befriending them-it was an attempt to show them the ropes, perhaps because they knew that new students would find little guidance on their own. In this anonymous environment, not only immigrants but also US-born students gravitated towards what felt most familiartheir own ethnic and racial groups.

In contrast, in London students developed close ties to Form Class peers with whom they shared all classes during multiple years. Form attended most of their classes together from Year 7 to Year 11. Even by Year 10, only math classes and up to two electives per day were not with the Form Class group. The Form Class structure led London students to bridge ethnic ties. Nathan, a white English student in Year 10, explained that racial separation happened only in the early years, before students got to know peers of other groups:

People, sometimes people do gang together with skin color. Though I don't really find that the case very much. That's only in Year 7 when people are just getting to know each other. So in this school, you quickly learn to become friends with all nationalities. Or you begin to go into the group which has very few friends.

As Nathan describes, once students have a chance to form close relationships within their Form Classes, they no longer feel the urge to cling to same-race peers. Nathan's description contrasts with the New York context, in which students never have the chance to form those close bonds within a Form Class and hence more often stayed in the same-race or sameethnicity groups that Nathan observed when his class first came together, in Year 7.

In addition, Long Meadow, with just over 1,000 students in a building with ample space, could offer lunch to all its students simultaneously. The school had two school-wide breaks during the day, during which time students could eat in the cafeteria, play in the schoolyard, roam the halls, or sit in the library or computer room. Finally, the school day began and ended with a morning 15 minute and afternoon 5-10 minute registration period with a Form Tutor, who usually followed the class through their years until age 16 (Year 11). 
During registration, the Form Tutor would take attendance, sometimes check students' school supplies, make announcements, and, when necessary, reprimand students (especially at the end of the day). Crucially, however, morning and afternoon registration was a time for most classes to socialize informally.

This overall structure of the Form Class, Form Tutor, and school-wide breaks contrasts with York High’s highly anonymous structure. Daily registration periods and two daily school-wide breaks provided time for students to socialize and form bonds based on interests in music, sports, and more, unlike the schedule at York in which at most students had a period for lunch to socialize, and where many had no non-academic time at school (those who didn't have a lunch period). These findings contrast with previous theorists who suggest that urbanization and industrialization lead to the breakup of traditional ties of birth membership (e.g., religion, ethnicity, family) and consequently lead to projects of selfrealization as an individual process, achieved through consumerism (Zukin \& Maguire, 2004). In fact, I found that the more atomized, bureaucratic school system in New York led to a stronger salience of ethnicity.

Of course myriad other differences distinguish the United States and Britain aside from school structure. I turn next to two commonly cited differences between Britain and the United States in terms of race relations, and evaluate their possible impact on the stronger ethnic and racial boundaries I found at York High: racial segregation and identity; and patterns of migration.

\section{RACIAL SEGREGATION AND IDENTITY}

Previous scholars have documented the degree to which the US society is racialized, in contrast to British society, where class defines social groups and even political mobilization more than race and ethnicity do (Foner, 2005; Modood, 1996). Because African Americans have the longest history in the US among racialized groups today, and until 
recently blacks were the largest minority group in the US, these dynamics have shaped US discourses around race and ethnicity overall, including with respect to immigrants and their children. Ethnic groups have benefited from the hard-earned victories of the Civil Rights Movement, such as affirmative action and anti-discrimination policies (Alba \& Nee, 2003; Kasinitz, Mollenkopf, Waters, \& Holdaway, 2008; Massey, Mooney, Charles, \& Torres, 2007; Skrentny, 2006).

In contrast, although Britain’s colonial history preceded the immigration of South Asians and West Indians to Britain and some have suggested that black identity has been excluded from British national identity (Gilroy, 1987), the legacy of racialization is weaker in Britain. Most significantly, urban America is significantly more residentially segregated by race than is London, especially for blacks, including black immigrants (Massey \& Denton, 1993; Peach, 1996). British schools are also considerably less segregated than urban American schools (Burgess \& Wilson, 2004). These patterns are reflected in intermarriage rates: Blacks are much more likely to marry whites in Britain than in the United States (Model \& Fisher, 2002). Hence, different histories of racial formation, leading to distinct patterns of segregation and intermarriage, may explain some of the differences described above between the symbolic boundaries of New York and London students.

However, the United States also has historically been a nation of immigrants, both demographically with waves of immigrants since its inception, and in its identity as a nation; this is not the case for Britain (Zolberg \& Long, 1999). Foner (2005) has documented the historical and contemporary construction of the ideal immigrant forefathers of the United States, in contrast to European erasure of immigration history in the popular imagination. The popular understanding of the United States as a "nation of immigrants" should have made the softening of ethnic boundaries smoother than in Britain. In addition, Alba and Nee (2003) have argued that US changes after the Civil Rights Movement such as anti- 
discrimination laws have decreased the social distance between minority groups and the majority, leading to the blurring of ethnic boundaries. New research has also shown that second generation teens and young adults in New York City engage and prefer cosmopolitan tastes and friendships networks (Kasinitz et al., 2008; Warikoo, 2004). In contrast, the British government's policies of multiculturalism have recently been blamed for fostering separation and preventing integration - that is, for encouraging stronger symbolic boundaries between ethnic and racial groups (Giddens, 2006; Goodhart, 2004). Hence, the different roles of race and ethnicity in British and American society doesn't seem to fully explain the findings described above.

\section{PATTERNS OF MIGRATION}

A greater percentage of New York City’s population is immigrants compared to London's (36\% versus 27\%). The parent populations at my research sites reflected this difference. At Long Meadow in London, 72\% of survey respondents' mothers were foreignborn, in contrast to $81 \%$ of mothers of York High students. The current wave of immigration to the US began in 1965, while Britain experienced significant immigration during the 1950s from the Caribbean and South Asia. This relative recency and larger proportion of immigrants in New York might account for the greater salience of ethnicity in New York, assuming that over time ethnicity’s salience will decrease for an ethnic community. Many scholars have found that, for example, native language usage drops sharply between the first and second generation (Portes \& Rumbaut, 2001; Rumbaut, 2004).

On the other hand, however, in the United States, many second generation AfroCaribbeans identify more strongly with minority (black or African American) identity than do their immigrant parents (Vickerman, 1999; Waters, 1999). And, recent research in Britain suggests that the second generation may identify more strongly with ethno-religious identity than their parents: 75\% of 45-54-year old Muslims polled in Britain said they felt that "I have 
as much in common with non-Muslims as I do with Muslims”, and that percentage decreased with every age group down to 15-24-year old British Muslims, $62 \%$ of whom agreed with the statement (Mirza, Senthilkumaran, \& Ja'far, 2006). In the survey I conducted in both schools, immigrant students were more likely than US- and UK-born respondents to agree with the statement In my school, students feel comfortable talking to students of other racial and ethnic groups on the school surveys, which suggests that in these school contexts being USor UK-born can actually mean stronger perceptions of racial division. Hence, immigrant communities having a longer history and smaller presence in London does not seem to fully explain the weaker ethnic and racial boundaries of teens at Long Meadow Community School compared to York High.

The design of this research cannot fully untangle the roles of residential segregation, ethno-racial identities, migration patterns, and other cross-national differences from school structure (Lieberson, 1992). Nevertheless, the evidence presented above suggests that the most promising explanation for the greater salience of race and ethnicity in the US context of this research is the highly anonymous school structure of urban America, especially when compared to the British context. Specifically, evidence in this article suggests that the Form Class and lunchtime structures in the two schools had a strong influence on symbolic boundaries, and in London led to the blurring of ethnic and racial boundaries. Given that children spend about one-third of their waking hours in school (Hofferth \& Sandberg, 2001), for children opportunities for socializing in school can make the difference between comfort with and distancing from other ethnic and racial groups.

Furthermore, anecdotal evidence suggests that smaller, more deliberately personalized high schools in New York have weaker racial and ethnic boundaries; and that students attending London colleges (serving ages 16-18 after the end of secondary school), which are 
generally organized similar to US universities, are more racially segregated than those in British secondary schools. In my own teaching at a small New York high school serving a diverse immigrant population, I observed frequent close friendships across ethnic and even linguistic lines. In Britain, my Master's students have reported to me that their friendship networks became more ethnically and racially separate when they finished secondary school and started Sixth Form or college (ages 16-18).

\section{DISCUSSION}

In this article I have demonstrated two aspects of urban multiethnic schools. First, multiethnicity leads to the blurring of ethnic and racial boundaries, both in the US and UK. Second, race and ethnicity determined the symbolic boundaries of students in a typical New York school more than for students in a typical London school. The evidence suggests that the traditional urban high school structure in the US, in contrast to London school structure, is an impediment to weakening racial and ethnic boundaries in New York. Although York High School in New York served a multiethnic school population, that multiethnicity was not enough to ensure strong inter-ethnic ties; rather, students needed structural opportunities to bridge racial and ethnic boundaries in school. This finding resonates with Allport's (1954) original conceptualization of the contact hypothesis—specifically, that reducing prejudice (and in this case, blurring the boundaries between ethnic and racial groups) is aided by institutional supports such as customs of racial interaction, and by "true” rather than "casual” contact, exemplified by the London Form Classes in contrast to the constantly shifting peers in the New York school. It follows that in order to promote ethnic and racial integration among teens, schools should not only serve integrated student bodies but also should maintain structures that present opportunities for students to bridge racial and ethnic 
boundaries. Varshney (2001) similarly suggests that in polarized multiethnic communities the structure of civic life can determine whether or not inter-ethnic violence will erupt.

These findings extend research done by Peshkin (1991) and Perry (2002) in multiethnic California high schools, by illustrating the important influence of school structure on how symbolic boundaries are drawn among students. Peshkin suggests that the history of efforts to improve strained race relations in the community of his research as well as stigmatization by surrounding wealthier communities led to greater solidarity across ethnic lines in his research. Its relative small size (1,500 students (Peshkin, 1991)) may have also played a role, according to my research. The cross-national comparison allowed me to focus on the traditional US urban schooling context, in contrast to Perry's (2002) focus on the racial make-up of the student body, and Peshkin’s (1991) focus on community history.

Other research in the United States has shown that small, intimate school structure can improve academic achievement in urban public schools where large, anonymous structure has been the tradition (Lawrence, 2004; Sizer, 1984). This has led to a vigorous small schools movement. The findings presented here suggest that in addition to improved academic achievement, small and intimate schools can also improve race relations. Specifically, schools that provide time to socialize and for students to get to know a small group of diverse peers will foster blurred racial and ethnic boundaries. This is one way in which careful school organization can positively respond to increased multiethnicity in urban schools, to promote inter-cultural understanding.

These implications may span the life course: other research has shown how Japanese preschools and elementary schools structure their instruction to foster cooperative values in the classroom and across skill levels, perhaps another way in which school-level decisions can improve race relations (Lewis, 1995; Peak, 1991). And, Rampersad (2007) has shown how university policies influence whether foreign post-graduate students integrate with their 
American peers at a public university in the United States. Given previous research showing that school integration improves the life chances of African American children, the blurring of racial and ethnic boundaries may have positive outcomes for second generation youth's futures, as well.

Finally, the research presented here extends previous discussions of how state institutions influence processes of ethnic assimilation via boundary crossing and blurring among ethnic groups (Alba, 2005; Wimmer, 2008b; Zolberg \& Long, 1999), to how school structures influences symbolic boundaries, and how they does so in social life. By doing so, I suggest that not only national institutions, but also local-level institutions can influence ethnic and racial boundaries. Furthermore, I have discussed the other types of symbolic boundaries experienced by teens when race and ethnicity do not define social life.

Future research should further disentangle the role of school structures from national institutions, which the design of this study did not allow for. That is, to what extent can school structure have a countereffect to migration patterns, residential segregation, and the history of racialization in the US? These variables could be separated through contrasting a study of small alternative schools in multiethnic areas of American cities with the results of this study. The findings in this article suggest that racial and ethnic boundaries differ not only at the national level, but will vary within countries as well. 
Table 1: The Schools in Comparison

\begin{tabular}{|c|c|c|c|c|}
\hline & & $\begin{array}{l}\text { New } \\
\text { York: } \\
\text { York } \\
\text { High } \\
\text { School }\end{array}$ & & $\begin{array}{l}\text { London: Long } \\
\text { Meadow } \\
\text { Community } \\
\text { School }\end{array}$ \\
\hline \multirow[t]{4}{*}{ Racial Makeup } & $\begin{array}{l}\text { Black (includes Afro- } \\
\text { Caribbean, African } \\
\text { American) }\end{array}$ & $13 \%$ & $\begin{array}{l}\text { Afro- } \\
\text { Caribbean }\end{array}$ & $15 \%$ \\
\hline & $\begin{array}{l}\text { Asian and Others } \\
\text { (includes Indian, } \\
\text { Indo-Caribbean, } \\
\text { other Asians, Mixed, } \\
\text { Native American) }\end{array}$ & $34 \%$ & Indian & $16 \%$ \\
\hline & White & $6 \%$ & White & $17 \%$ \\
\hline & Hispanic & $47 \%$ & $\begin{array}{l}\text { Mixed, Other, } \\
\text { or } \\
\text { Unspecified }\end{array}$ & $25 \%$ \\
\hline $\begin{array}{l}\text { Number of } \\
\text { Students }\end{array}$ & & 3,500 & & 1,180 \\
\hline $\begin{array}{l}\text { Free Lunch } \\
\text { Eligibility }\end{array}$ & & $34 \%$ & & $33 \%$ \\
\hline $\begin{array}{l}\text { Exam/Graduation } \\
\text { Results }\end{array}$ & graduation rate & $38 \%$ & $\begin{array}{l}\text { At least } 5 \text { A- } \\
\text { C GCSEs }\end{array}$ & $43 \%$ \\
\hline
\end{tabular}

Sources: UK Office of Standards in Education School Reports, 1998, 2004; NY State Department of Education School Report Card, 2005-06; NYC Department of Education School Report Card, 2004-05

Table 2: School Social Groups

New York

London

Source: Interview data, $\mathrm{n}=86^{\mathrm{xiii}}$

*Percentages do not add up to $100 \%$, because some students mentioned more than one kind of group and others gave responses not listed here.
Social Groups

Race/Ethnicity (66\%)

Popularity (16\%)

Taste (16\%)

Form Class (33\%)

Gender (24\%)

Taste (24\%)

Lunchtime Activities (20\%)

Race/Ethnicity (20\%) 
Table 3: "Which groups at school do you feel comfortable/uncomfortable with?”

\begin{tabular}{lll}
\multirow{2}{*}{ New York } & $\begin{array}{l}\text { Comfortable } \\
\text { Race/Ethnicity (34\%) }\end{array}$ & $\begin{array}{l}\text { Uncomfortable } \\
\text { None (43\%) } \\
\text { None (31\%) }\end{array}$ \\
...Race/Ethnicity (20\%) \\
London & $\begin{array}{l}\text { None (29\%) } \\
\text { Form Class (20\%) }\end{array}$ & None (56\%) \\
& ...Race/Ethnicity (2\%) \\
& ..Race/Ethnicity (2\%) &
\end{tabular}

Source: Interview data, $\mathrm{n}=86$

Percentages do not add up to $100 \%$, because some students mentioned more than one kind of group, and others gave responses not listed here.

\section{Table 4: Popularity}

New York

London
Race/Ethnicity (43\%)

Misbehavior or Bullying (37\%)

Don't know or There are none (17\%)

Don’t know or There are none (35\%)

Known, loud, or big social group (31\%)

Taste (20\%)

Form Class individuals (16\%)

Misbehavior or bullying (15\%)

Source: Interview data, $\mathrm{n}=86$

Percentages do not add up to $100 \%$, because some students mentioned more than one kind of group, and others gave responses not listed here.

Table 5: Descriptions of Unpopular Students

New York

Race/Ethnicity (46\%)

Quiet, Loner, no Socializing (23\%)

Don’t Know (19\%)

London Quiet, Loners (36\%)

There are none (28\%)

Don't Know (19\%)

Source: Interview data, $\mathrm{n}=73^{\mathrm{xiv}}$

... Race (4\%)

Percentages do not add up to $100 \%$, because some students mentioned more than one kind of group, and others gave responses not listed here. 


\section{REFERENCES}

Adler, P. A., \& Adler, P. (1998). Peer Power: Preadolescent Culture and Identity. New Brunswick: Rutgers University Press.

Alba, R. D. (2005). Bright vs. blurred boundaries: Second-generation assimilation and exclusion in France, Germany, and the United States. Ethnic and Racial Studies 28(1), 20-49.

Alba, R. D., \& Nee, V. (2003). Remaking the American mainstream : assimilation and contemporary immigration. Cambridge, Mass.: Harvard University Press.

Allport, G. W. (1954). The nature of prejudice. Cambridge, Mass.,: Addison-Wesley Pub. Co.

Barth, F. (1969). Introduction. In F. Barth (Ed.), Ethnic groups and boundaries. The social organization of culture difference (pp. 9-38). Bergen and Prospect Heights, Il: Universitetsforlaget and Waveland Press.

Burgess, S., \& Wilson, D. (2004). Ethnic segregation in England's schools. CASE paper (No. 79): Centre for the Analysis of Social Exclusion, London School of Economics.

Coleman, J. S. (1961). The adolescent society; the social life of the teenager and its impact on education. [New York]: Free Press of Glencoe.

Conchas, G. Q. (2001). Structuring Failure and Success: Understanding the Variability in Latino School Engagement. Harvard Educational Review, 71(4), 475-504.

Crain, R. L., \& Mahard, R. E. (1978). School racial composition and black college attendance and achievement test performance Sociology of Education, 51(2), 81-101.

Dawkins, M. P., \& Braddock Ii, J. H. (1994). The continuing significance of desegregation: School racial composition and African American. Journal of Negro Education, 63(3), 394.

Eder, D. (1985). The Cycle of Popularity: Interpersonal Relations among Female Adolescents. Sociology of Education, 58(3), 154-165.

Eder, D., \& Kinney, D. A. (1995). The Effect of Middle School Extracurricular Activities on Adolescents' Popularity and Peer Status. Youth and Society, 26(3), 298-324.

Fasenfest, D., \& Booza, J. (2007). Living Together, Living Apart: Racial and Ethnic Integration in Metropolitan Neighborhoods, 1970-2000. In P. Davies \& I. Morgan (Eds.), America's Americans: Population Issues in US Society and Politics. London: Institute for the Study of the Americas.

Flores-González, N. (2002). School kids/street kids : identity development in Latino students. New York: Teachers College Press.

Foner, N. (2005). In a new land : a comparative view of immigration. New York: New York University Press.

Fong, E., \& Shibuya, K. (2005). Multiethnic cities in North America Annual Review of Sociology, 31(1), 285-304.

Giddens, A. (2006, October 14, 2006). Misunderstanding multiculturalism. The Guardian,

Gilroy, P. (1987). "There ain't no black in the Union Jack" : the cultural politics of race and nation. London: Hutchinson.

Goodhart, D. (2004). Too diverse? Prospect.

Hallinan, M. T. (1982). Classroom Racial Composition and Children's Friendships. Social Forces, 61(1), 56-72.

Hewstone, M., \& Brown, R. (1986). Contact is not Enough: An Intergroup Perspective on the "Contact Hypothesis". In M. Hewstone \& R. Brown (Eds.), Contact and conflict in intergroup encounters (pp. 1-44). Oxford, UK ; New York, NY, USA: Blackwell.

Hofferth, S. L., \& Sandberg, J. E. (2001). How American Children Spend Their Time. Journal of Marriage \& Family, 63(2), 295. 
Joyner, K., \& Kao, G. (2000). School Racial Composition and Adolescent Racial Homophily. Social Science Quarterly 81(3), 815-825.

Kasinitz, P., Mollenkopf, J. H., Waters, M. C., \& Holdaway, J. (2008). Inheriting the City: The Children of Immigrants Come of Age. Cambridge: Harvard University Press.

Lamont, M. (1992). Money, morals, and manners : the culture of the French and American upper-middle class. Chicago: University of Chicago Press.

Lamont, M. (2000). The dignity of working men : morality and the boundaries of race, class, and immigration. New York and Cambridge: Russell Sage Foundation and Harvard University Press.

Lamont, M., \& Molnar, V. (2002). The Study of Boundaries in the Social Sciences. Annual Review of Sociology 28, 167-195.

Lawrence, B. K. (2004). For Authentic Accountability Think Small. Journal of Education, 185(3), 41.

Lee, V. E. (2000). School Size and the organization of Secondary Schools. In M. T. Hallinan (Ed.), Handbook of the Sociology of Education (pp. 327-344). New York: Kluwer Academic/Plenum.

Lewis, C. C. (1995). Educating hearts and minds : reflections on Japanese preschool and elementary education. Cambridge ; New York: Cambridge University Press.

Lieberson, S. (1992). Small N's and big conclusions: an examination of the reasoning in comparative studies based on a small number of cases. In C. C. Ragin \& H. S. Becker (Eds.), What is a Case? Exploring the Foundations of Social Inquiry (pp. 105-118). Cambridge: Cambridge University Press.

Massey, D. S., \& Denton, N. A. (1993). American Apartheid: Segregation and the Making of the Underclass. Cambridge, MA: Harvard University Press.

Massey, D. S., \& Fischer, M. J. (2006). The effect of childhood segregation on minority academic performance at selective colleges. Ethnic \& Racial Studies, 29(1), 1-26.

Massey, D. S., Mooney, M., Charles, C. Z., \& Torres, K. C. (2007). Black Immigrants and Black Natives Attending Selective Colleges and Universities in the United States. American Journal of Education, 113(2), 243.

Merten, D. E. (1997). The Meaning of Meanness: Popularity, Competition, and Conflict among Junior High School Girls. Sociology of Education 70, 175-191.

Milner, M. (2004). Freaks, Geeks, and cool kids : American teenagers, schools, and the culture of consumption. New York: Routledge.

Mirza, M., Senthilkumaran, A., \& Ja'far, Z. (2006). Living apart together: British Muslims and the paradox of multiculturalism. London: Populus and Policy Exchange.

Model, S., \& Fisher, G. (2002). Unions between blacks and whites: England and the US compared. Ethnic and Racial Studies 25(5), 728-754.

Modood, T. (1996). The Limits of America: Rethinking Equality in the Changing Context of British Race Relations. In B. Wardf \& T. Badger (Eds.). New York: New York University.

Mouw, T., \& Entwisle, B. (2006). Residential Segregation and Interracial Friendship in Schools. American Journal of Sociology, 112(2), 394-441.

Peach, C. (1996). Does Britain have ghettos? Transactions of the Institute of British Geographers 21(1), 216-235.

Peak, L. (1991). Learning to go to school in Japan : the transition from home to preschool life. Berkeley: University of California Press.

Perry, P. (2002). Shades of white : white kids and racial identities in high school. Durham, NC: Duke University Press.

Peshkin, A. (1991). The color of strangers, the color of friends : the play of ethnicity in school and community. Chicago: University of Chicago Press. 
Portes, A., \& Rumbaut, R. G. (2001). Legacies : the story of the immigrant second generation. Berkeley and New York: University of California Press and Russell Sage Foundation.

Rampersad, C. (2007). Diversity in question: Inclusionary and exclusionary social interactions among international graduate students. Pennsylvania State University, University Park.

Rumbaut, R. (2004). Ages, Life Stages, and Generational Cohorts: Decomposing the Immigrant First and Second Generations in the United States. International Migration Review 38(3), 1160-1205.

Sizer, T. R. (1984). Horace's compromise : the dilemma of the American high school. Boston: Houghton Mifflin.

Skrentny, J. D. (2006). Policy-Elite Perceptions and Social Movement Success: Understanding Variations in Group Inclusion in Affirmative Action. American Journal of Sociology, 111(6), 1762-1815.

Tyack, D. B. (1974). The one best system : a history of American urban education. Cambridge, Mass.: Harvard University Press.

Tyack, D. B., \& Cuban, L. (1995). Tinkering toward utopia : a century of public school reform. Cambridge, Mass.: Harvard University Press.

Valenzuela, A. (1999). Subtractive schooling : issues of caring in education of U.S.-Mexican youth. Albany: State University of New York Press.

Varshney, A. (2001). Ethnic conflict and civil society World Politics, 53(3), 362.

Vertovec, S. (2007). Super-diversity and its implications. Ethnic \& Racial Studies, 30(6), 1024-1054.

Vickerman, M. (1999). Crosscurrents : West Indian immigrants and race. New York: Oxford University Press.

Warikoo, N. (2004). Cosmopolitan Ethnicity: Second Generation Indo-Caribbean Identities. In P. Kasinitz, J. H. Mollenkopf \& M. C. Waters (Eds.), Becoming New Yorkers: Ethnographies of a New Second Generation New York: Russell Sage Foundation.

Warikoo, N. (forthcoming). Balancing Acts: Youth Culture among Children of Immigrants in New York and London. Berkeley: University of California Press.

Waters, M. C. (1999). Black identities : West Indian immigrant dreams and American realities. New York and Cambridge, Mass.: Russell Sage Foundation and Harvard University Press.

Wimmer, A. (2007). How (not) to think about ethnicity in immigrant societies: A boundary making perspective (No. Working Paper No. 44). Oxford: ESRC Centre on Migration, Policy and Society, University of Oxford.

Wimmer, A. (2008a). Elementary Strategies of Ethnic Boundary making. Ethnic \& Racial Studies, 31(6), 1025-1055.

Wimmer, A. (2008b). The Making and Unmaking of Ethnic Boundaries: A Multilevel Process Theory. American Journal of Sociology, 113(4), 970-1022.

Zolberg, A. R., \& Long, L. W. (1999). Why Islam is Like Spanish: Cultural Incorporation in Europe and the United States. Politics and Society, 27(1), 5-38.

Zukin, S., \& Maguire, J. S. (2004). Consumers and Consumption. Annual Review of Sociology 30(1), 173-198.

\section{ENDNOTES}

Acknowledgments. The author is grateful for guidance and assistance on this research from Mary Waters, Michéle Lamont, Prudence Carter, and Andreas Wimmer. This research has 
also benefited from the support of the NSF-IGERT Program, "Multidisciplinary Program in Inequality \& Social Policy" at Harvard University (Grant No. 9870661); the NSF Dissertation Improvement Award (SES-0402248); and the Minda de Gunzburg Center for European Studies Dissertation Research Award. This paper was presented at the 2006 Council for European Studies Conference and at Oxford University's Centre on Migration Policy and Society, and has benefited from comments and feedback at those forums.

\footnotetext{
${ }^{i}$ Large school size is a result of the history of bureaucratization of US schooling during the turn of the last century, which was instituted in part to deal with large scale urban growth, predominantly through immigration (Lee, 2000; Tyack, 1974). The solution to overcrowding today has been to get students in and out of the building as soon as possible, sacrificing down time for students in school.

ii US high schools traditionally move students from class to class with different peer groups for most subjects; this system was seen as a way of high specialization and efficiency made possible through large school size (V. E. Lee, 2000; Tyack, 1974). Once institutionalized, American school structure has proven difficult to change (Tyack \& Cuban, 1995).

iiiThroughout this article I have changed the names of the schools, students, and teachers in the interest of confidentiality.

iv Because school statistics count Asians together with those in the "other" category, this figure may be slightly high.

${ }^{v}$ A school administrator at York High School explained to me that because many students do not have a lunch period at her school, many do not bring in their free/reduced lunch form. When the school did a drive to get all students to return application forms for free school meals in $2005,87 \%$ of students became eligible for free school meals.

vi The GCSE exams are the exit exams for schooling in the UK, taken at age 16.

vii Indo-Caribbean students' parents came from the Caribbean (predominantly Guyana and Trinidad); their ancestors came from India to the Caribbean as indentured laborers during the $19^{\text {th }}$ and early $20^{\text {th }}$ centuries. Today, about half of Guyana and Trinidad's populations are Indo-Caribbean.

viii Because almost all of the Caribbean and Indian youth I interviewed were second generation, in this article I only indicate when someone is not second generation.

ix Many students listed more than one type of social group, and others described groups not listed here; hence, the percentages do not add up to $100 \%$.

x In addition, tracked classes had about one-third of the pupils from students' Form Classes, and gym classes have all their same-gender Form Class peers.

${ }^{x i}$ Milner (2004) points out that the relationship between visibility ("being known" as some youth in my study called it), popularity, and status is complicated. Visibility is necessary for status, in order for others to recognize one's status. However, the recognition could be negative, as in a peer who is overly aggressive. Although peers may recognize popular students' status, they don't always approve of those peers, or even like them.

xii The majority of Indian students at York High were Punjabi Sikhs, so at the school the terms "Indian” and "Punjabi” were synonymous. Elsewhere I have written about why Indians had low peer status and blacks high peer status (Warikoo, forthcoming).

xiii Although there were 120 interview respondents, due to time constraints some were not asked the questions on social groups and popularity, because preliminary interviews with a range of students addressed questions regarding school social groups and peer hierarchies. I do not include preliminary interview data in the final results.

${ }^{\text {xiv }}$ As described earlier, not all students were asked the core questions on status and social groups at school. Furthermore, those who said "I don't know" in response to who was popular at school were not asked about who was unpopular. Hence, I show data from 73 student responses here.
} 